\title{
Market Hog Project Financial Considerations ${ }^{1}$
}

\section{Alyssa Schortinghouse, Brian Estevez, Chad Carr, and Nick Simmons ${ }^{2}$}

\section{Purpose and Audience}

The aim of this document is to introduce the financial considerations for a market hog project, to maximize profits for the project and to demystify the unexpected expenses that are often incurred. Secondarily, this document is designed to serve as a guide in creating a market hog project budget. The audience for this document includes youth interested in or participating in a market hog project, their families, and other interested parties.

\section{Introduction}

A market hog project often presents an ideal project for youth who are interested in stepping out of smaller livestock projects, but who are not yet ready to start working with larger project animals such as cattle. Market hog projects are most often medium-term projects, with the entire timeline from purchase to sale lasting from less than six months to a year. Market swine projects are ideal for a number of reasons. First, a market-ready hog project weighs roughly 280 to 300 pounds, which is less intimidating than that of a 1,100-to-1,300-pound steer project. Secondly, the amount of startup money required is considerably less than for larger project animals. While the purpose of a market hog project is multifaceted, these projects do not have to be viewed as cost prohibitive. If correctly done, a market animal project should provide youth with enough seed money to continue to invest in future projects, as well as instill personal responsibility and the basic knowledge of caring for a food-producing animal.

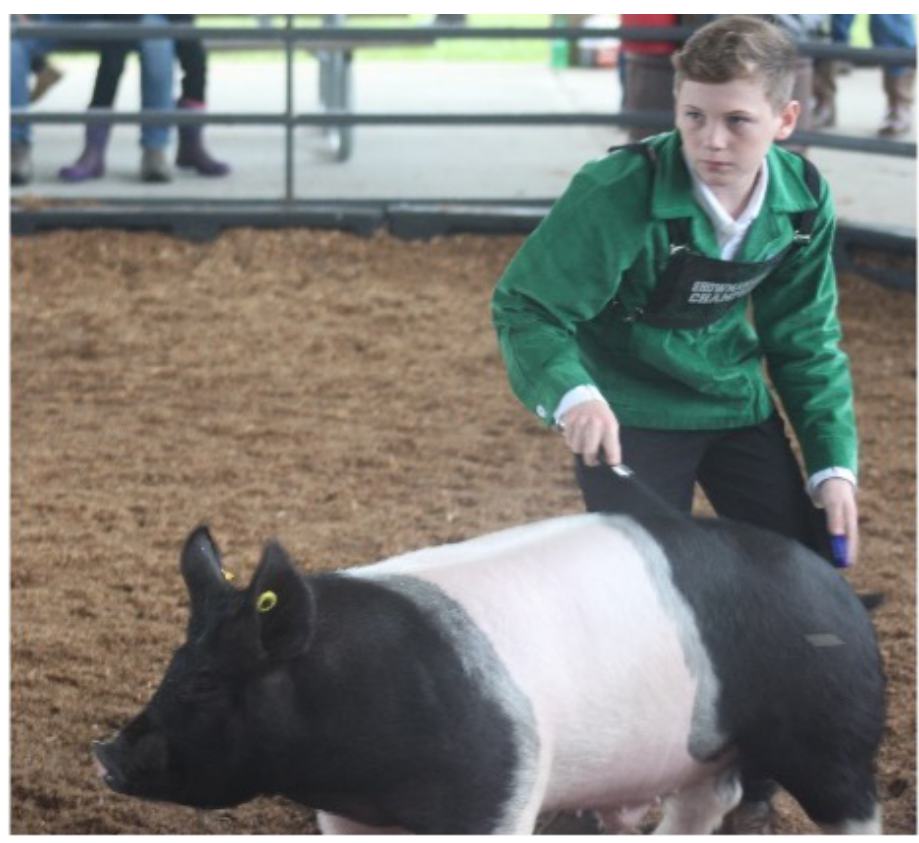

Figure 1. Florida $4-\mathrm{H}$ youth showing a $4-\mathrm{H}$ market swine project at a show in 2021.

Credits: Aly Schortinghouse, UF/IFAS

\section{The Basics}

In this document, we will consider two primary types of costs, startup costs and operating costs. These costs only cover the necessities needed to successfully raise a $4-\mathrm{H}$ market hog project and do not account for any specialized products or additional showing adventures that might be pursued with a project animal. Additional financial costs may be incurred if a youth elects to use supplements, specialized supplies, or even experiences unpredictable

1. This document is 4H426, one of a series of the Florida 4-H Youth Development Program, UF/IFAS Extension. Original publication date February 2022. Visit the EDIS website at https://edis.ifas.ufl.edu for the currently supported version of this publication.

2. Alyssa Schortinghouse, Extension agent I, UF/IFAS Extension Escambia County; Brian Estevez, Extension agent III, UF/IFAS Extension Escambia County; Chad Carr, associate professor and state meat Extension specialist, UF/IFAS Department of Animal Sciences; and Nick Simmons, county Extension director and Extension agent II, UF/IFAS Extension Escambia County; UF/IFAS Extension, Gainesville, FL 32611.

The Institute of Food and Agricultural Sciences (IFAS) is an Equal Opportunity Institution authorized to provide research, educational information and other services

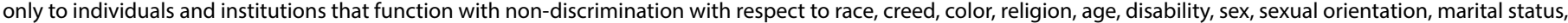

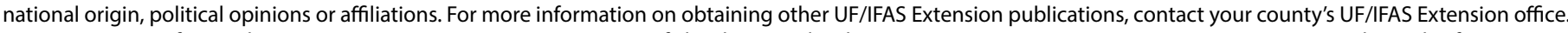
U.S. Department of Agriculture, UF/IFAS Extension Service, University of Florida, IFAS, Florida A \& M University Cooperative Extension Program, and Boards of County Commissioners Cooperating. Andra Johnson, dean for UF/IFAS Extension. 
health issues with an animal. While we did not account for these costs, it is advisable that each project considers an emergency account in which funds are allocated for these unexpected costs.

Each market animal project will have its own unique financial needs and outcomes. In the process of introducing the various types of financial considerations for starting a market hog project, we reference the Market Hog Project Projected Budget Tool. A static version of this tool may be found in Appendix A, with a working document available through this link: https://docs.google.com/spreadsheets/d/1 fcrytZcWwAnMKsYHb8zDSVdHgaVs3tYD/edit?usp=shari ng\&ouid=11 1328222695062374437\&rtpof=true\&sd=true.

To use this document, it advised that you download or save the file in your own storage location to ensure others do not overwrite your inputs through the shared version. This tool includes the projected budget referenced below. This document also includes an Excel document with a tab where it is possible to customize your own project budget. Note that the document will calculate the costs, breakeven price, and even the project take-home once the numbers are entered. As such, we recommend using this tool to make a budget for each project in order to track and assess the project and its expected financial outcomes most accurately.

${ }^{\star}$ While we are providing estimated costs, it is critical that youth conduct their own research and update this projected budget tool with actual costs based on their findings. This method will provide a more accurate estimation of project costs.

\section{Project Costs}

\section{Startup Costs}

There are three primary types of startup costs to consider: housing, equipment, and supplies. Startup costs are incurred the first year of a project when starting from scratch. These costs often last through multiple years of a project and may even be considered long-term assets. Startup costs include shelter, fencing, a feeder or feeding equipment, water equipment, and other miscellaneous equipment such as sorting boards. There are many methods to reduce these costs, including seeking donations for these supplies, partnering with a local entity that has facilities, or working with others raising project animals together and sharing facilities.

${ }^{\star}$ If you would like to learn more about the needs for raising a swine project animal, please reference Raising a Market Show Hog at https://edis.ifas.ufl.edu/publication/4H407.
While these projects are incurred over the course of a project, due to the fact they are intended for use over the course of many years and projects, we do not account for these costs in calculations, though they are considered necessary for the completion of a project.

1.Housing: These costs are specifically in reference to the needs for providing a safe pen to raise a market hog project animal in. Housing costs may also include fencing, panels, or the cost of a structure to provide shelter. We budget for shelter, fencing, and any miscellaneous supplies that might be needed, such as fencing staples or fencing tools. As you prepare your shelter, keep in mind the pig needs a place to be out of the sun and should also have a windbreak.

\begin{tabular}{|l|l|}
\hline \multicolumn{2}{|c|}{ Housing } \\
\hline Item & Budgeted \\
\hline Shelter/Barn & $\$ 2,500.00$ \\
\hline Fencing/Panels & $\$ 150.00$ \\
\hline Miscellaneous & $\$ 50.00$ \\
\hline Total & $\mathbf{\$ 2 , 7 0 0 . 0 0}$ \\
\hline
\end{tabular}

2. Equipment: These costs include buckets or pans used for feeding or offering water, the various components of the watering systems, such as hoses, piping, and the water nipple, storage supplies such as trash cans or barrels, and any miscellaneous equipment that might be needed.

\begin{tabular}{|l|l|}
\hline \multicolumn{2}{|c|}{ Equipment } \\
\hline Item & Budgeted \\
\hline Feeding Supplies & $\$ 20.00$ \\
\hline Watering Supplies & $\$ 30.00$ \\
\hline Storage & $\$ 40.00$ \\
\hline Miscellaneous & $\$ 25.00$ \\
\hline Total & $\$ 115.00$ \\
\hline
\end{tabular}

3. Supplies: These costs often include items that may be used for multiple years, such as rice root brushes, a show whip or stick, and any miscellaneous supplies you might need through the year. Miscellaneous supplies could include a specific pair of jeans or could account for the need to replace buckets if one is destroyed.

\begin{tabular}{|l|l|}
\hline \multicolumn{2}{|c|}{ Supplies } \\
\hline Item & Budgeted \\
\hline Grooming & $\$ 20.00$ \\
\hline Showing & $\$ 30.00$ \\
\hline Miscellaneous & $\$ 50.00$ \\
\hline Total & $\$ 100.00$ \\
\hline
\end{tabular}




\section{Operating Costs}

The second type of costs for a project is operating costs. Operating costs will occur with each year with each project animal. These costs will be incurred depending on the needs of each animal and the goals of each project. Operating costs include the initial animal purchase price, feed, entry fees, wormer and other health costs, veterinary expenses, equipment including brushes and show whips, bathing supplies such as shampoo and hide conditioner, and marketing expenses.

1. Maintenance: These costs often have the most variability within project areas, especially in pig projects. In Florida specifically, costs are often increased due to having to ship the grains from the areas where they are produced (Crosswhite et al., 2019). There are numerous methods through which to procure feed, including from a feed store, from a dealer, or directly from a milling company (Brendenmuhl \& Myer, 2016). As such, costs will vary depending on where the feed is bought in addition to the type of ration (starter, grower, etc.) being fed throughout the various growth stages. Feeds will often range in cost from $\$ 12$ to $\$ 25$ per 50 -pound bag. In a traditional production setting, it is estimated that 650 pounds of complete feed is needed to grow a pig from birth to slaughter (Crosswhite et al., 2019). As such, it is estimated that a pig will eat 700 pounds of feed over the course of a project. It is estimated that the feed will cost $\$ 20$ per 50 pounds $(700$ pounds $/ 50$ pounds $=14$ bags of feed; 14 bags of feed will cost $\$ 20$ per bag $=\$ 280$, which we rounded down to an estimated $\$ 250$ ). This estimation will vary depending on the length of project and the project animal's needs. As such, it is recommended to purchase a complete pig feed from a national brand or a reputable feed mill.

There are many types of bedding that may be utilized for a hog project. Bedding not only helps prevent scratches, but also provides a means for swine to keep warm during temperature dips. While Florida is known for its warm days, it also commonly experiences temperature dips at night, and a deeply bedded area, in addition to other tools such as heat lamps when necessary, will help swine to fight the cold.

\begin{tabular}{|l|l|}
\hline \multicolumn{2}{|c|}{ Maintenance } \\
\hline Item & Budgeted \\
\hline Feed & $\$ 250.00$ \\
\hline Minerals & $\$ 25.00$ \\
\hline Bedding & $\$ 100.00$ \\
\hline Total & $\$ 375.00$ \\
\hline
\end{tabular}

${ }^{\star}$ If you would like to learn more about 4-H market hog project nutrition, please refer to $4 H$ Project Guide: Swine Nutrition at https://edis.ifas.ufl.edu/4H225. Please note edits to this document are anticipated in 2022.

2. Animal: There are many different sources from which to get project animals. Cost does not necessarily equate to quality, so carefully choose who you use to source your project animals. These costs also include anything that may need to be used on the animal throughout the project, including shampoos, conditioners, and lotions. Also, budget for any small miscellaneous purchases that may be needed, such as a washing brush or sponges.

\begin{tabular}{|l|l|}
\hline \multicolumn{2}{|c|}{ Animal } \\
\hline Item & Budgeted \\
\hline Purchase Cost & $\$ 250.00$ \\
\hline Washing & $\$ 20.00$ \\
\hline Miscellaneous & $\$ 25.00$ \\
\hline Total & $\mathbf{\$ 2 9 5 . 0 0}$ \\
\hline
\end{tabular}

3. Project: Project costs include any entry fees for shows, the travel costs to the show and any costs incurred through marketing your animal or even yourself. It is often advisable to include a budget for the miscellaneous costs that might occur or to utilize this section as an emergency budgeted line. In the projected budget, we only accounted for one show's entry fees and travel costs. Marketing costs may include the cost of printing out buyer letters or making posters to promote your animal to potential buyers. While a buyer thank-you gift is not required, in most instances, a buyer thank-you gift such as a small mug in addition to a personalized thank-you letter is considered good etiquette.

\begin{tabular}{|l|l|}
\hline \multicolumn{2}{|c|}{ Project } \\
\hline Item & Budgeted \\
\hline Entry Fees & $\$ 50.00$ \\
\hline Travel & $\$ 50.00$ \\
\hline Marketing & $\$ 25.00$ \\
\hline Buyer Thank-You Gift & $\$ 25.00$ \\
\hline Miscellaneous & $\$ 0.00$ \\
\hline Total & $\mathbf{\$ 1 5 0 . 0 0}$ \\
\hline
\end{tabular}

The total project costs that are incurred are often determined by how invested a youth gets into the project. For example, a youth who emphasizes showing will accumulate more costs from attending more shows, as show fees, gas, and other miscellaneous fees are added. All project animals have the potential to be competitive given solid genetics and provided the correct environment to grow. Remember that the best way to maximize profits from a project is to 
minimize the costs. While this is the best way to maximize profits, we must not compromise our ethical standards in the name of earning more money. As such, it is essential that each project is carefully planned and budgeted for to ensure that it will uphold ethical standards and allow us to maximize our profits at the same time.

\section{Project Income}

There are a few ways to generate income or assets through market animal projects. The primary ways to earn income includes the final sale of the animal at auction, financial support, and in-kind support.

1. Final Sale: In most cases, it is the responsibility of youth completing market animal projects to pursue and secure buyers for their project animals. When talking with buyers, it is critical to understand the financial nuances of a project. When conversing with potential buyers, more than likely you will only discuss the operational costs, or the costs you accrue on a yearly basis. In a later section, we cover the break-even price per pound in more detail. The final sale price is not set and final until the bid has been placed at auction. For the purposes of our projected budget, we anticipate the animal will bring $\$ 3$ per pound, with the final weight of 280 pounds resulting in the final sale income equating to $\$ 840$ ( $\$ 3$ per pound $\times 280$ pounds $=\$ 840$ ). Each project has the chance to bring more or less than this projected baseline, though if a buyer is not secured it is possible that the project could result in a net loss, because this is the largest percentage of income on average.

\begin{tabular}{|l|l|}
\hline \multicolumn{2}{|c|}{ Final Sale } \\
\hline Item & Budgeted \\
\hline Sale & $\$ 840.00$ \\
\hline Total & $\$ 840.00$ \\
\hline
\end{tabular}

*If you would like to learn more about market hog carcass merits as, please reference Ultrasound and Carcass Merit of Youth Market Hogs at https://edis.ifas.ufl.edu/publication/ AN252.

2. Monetary Support: It is not uncommon to receive monetary donations from family members or even sponsorships from local supporters. It is essential to carefully track this for record-keeping purposes such as record books and even end-of-project thank-you letters. Even if a family member gives ten dollars, proper etiquette is to thank them for their donation through a thank-you letter or even through project updates. The way through which this is done is up to the individual. While we do not account for this in the projected budget, it is beneficial to seek financial support to offset costs such as feed and bedding.

\begin{tabular}{|l|l|}
\hline \multicolumn{2}{|c|}{ Monetary Support } \\
\hline Item & Budgeted \\
\hline Sponsorships & $\$ 0.00$ \\
\hline Money Donations & $\$ 0.00$ \\
\hline Total & $\mathbf{\$ 0 . 0 0}$ \\
\hline
\end{tabular}

3. In-Kind Support: This type of support occurs when a physical good is donated or given for the purposes of completing the project. This could be a donation of a bag of feed, hay, or even panels. While not physical money, in-kind goods should be tracked just as carefully as the financial support that is received. To estimate the value of a donated good, it is often advised that research of equitable products is done to determine a good's value.

\begin{tabular}{|l|l|}
\hline \multicolumn{2}{|c|}{ In-Kind Support } \\
\hline Item & Budgeted \\
\hline Donated Items & $\$ 0.00$ \\
\hline Total & $\mathbf{\$ 0 . 0 0}$ \\
\hline
\end{tabular}

\section{Project Outlook}

It is always important to track project costs and income, and in doing so, it is possible to project the price the animal needs to sell at to break even as well as determine the net income or loss of the project.

1.Project Costs: For simplicity's sake, we summarized all the projected costs into one table titled Project Costs. Note that the housing, equipment, and supply categories that compose startup costs are not factored into the calculations below focused on the break-even price and the projected take-home of the project. Only the raising, animal, and project categories, which compose the operational costs, are accounted for in the later discussion. Over time the startup costs will be paid off and should not be accounted for with every project nor each year a project is completed. In most cases these costs will be one-time purchases, which is why they are projected but not accounted in later calculations.

2. Break-Even Price: The break-even price is how much is needed per pound of animal to result in the project earning zero dollars. While there are many factors which impact meat quality, an ideal market weight for a markethog project ranges from 280 to 300 pounds, which is the range most likely to generate consumer preferred retail cuts (Carr et al., 2020). As such, for the projected 
budget it is estimated the animal will weigh 280 pounds. By taking the total operational costs from the projected budget and dividing by the final weight at sale, we get the price needed per pound to break even at the sale ( $\$ 820$ Operational Costs $/ 280$ pounds $=\$ 2.93$ ). When discussing prices with a potential buyer, this estimate will help them understand your project's financial status. In most cases, this will serve as a baseline for buyers when offering to bid on your animal at a sale. The income minus the operational costs results in the total gain or loss of the project.

\begin{tabular}{|l|l|l|l|}
\hline \multicolumn{4}{|c|}{ Project Costs } \\
\hline Category & $\begin{array}{l}\text { Category } \\
\text { Total }\end{array}$ & Subtotal & Overall Total \\
\hline Housing & $\$ 2,700.00$ & $\$ 2,915.00$ & $\$ 3,735.00$ \\
\hline Equipment & $\$ 115.00$ & & \\
\hline Supply & $\$ 100.00$ & & \\
\hline Raising & $\$ 375.00$ & $\$ 820.00$ & \\
\hline Animal & $\$ 295.00$ & & \\
\hline Project & $\$ 150.00$ & & \\
\hline
\end{tabular}

\begin{tabular}{|l|l|}
\hline \multicolumn{2}{|c|}{ Project in Review } \\
\hline Project Final Weight at Sale & 280 \\
\hline Break-Even Sale Price per lb & $\$ 2.93$ \\
\hline Net Income & $\$ 20.00$ \\
\hline
\end{tabular}

\section{Conclusions}

Each project will vary in its specifications, costs, and income. This document projected the middle ground in terms of project cost, but it is the responsibility of each project participant to carefully plan for each project individually with the supplies that are available to them. The project budget tool accounts for the financial project outlook on a per-animal basis, and as such it is recommended to complete a projected budget for each project animal each year. While hog projects teach essential life skills, it is easy for the projects to result in a financial loss if not properly planned for. Therefore, it is critical to understand what the project entails in terms of a financial commitment. The aim of this document is to provide insight as to the various financial considerations of raising a market hog project animal to ensure the youth and their families are able to reap the benefits the projects stand to offer.

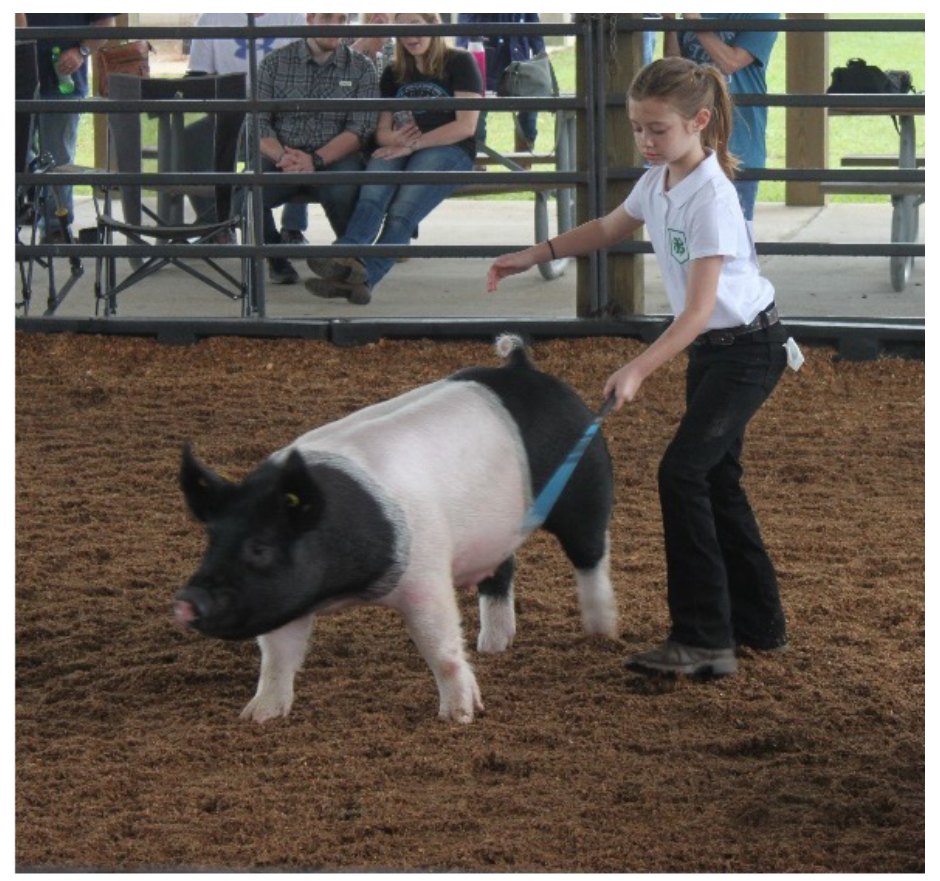

Figure 2. Florida 4-H youth showing a 4-H market swine project in 2021.

Credits: Aly Schortinghouse, UF/IFAS

\section{References}

Brendenmuhl, J. H., \& Myer, R. O. (2016, December 14). 4H Project Guide: Swine Nutrition. EDIS, 2004(8). https:// edis.ifas.ufl.edu/publication/4H225

Carr, C., Johnson, D., \& Shuffitt, M. (2020, November 4). Ultrasound and Carcass Merit of Youth Market Hogs. EDIS, 2010(7). https://edis.ifas.ufl.edu/publication/AN252

Crosswhite, J. D., Myers, N. B., Adesogan, A. T., Brendemuhl, J. H., Johnson, D. D., \& Carr, C. C. (2019, January 21). Feeding Ensiled Citrus Pulp to Finishing Pigs. EDIS, 2012(8). https://edis.ifas.ufl.edu/publication/AN282 
Appendix A

\section{Market Hog Project Projected Budget Overview}

\section{Startup Costs}

\begin{tabular}{|l|l|}
\hline \multicolumn{2}{|c|}{ Housing } \\
\hline Item & Budgeted \\
\hline Shelter/Barn & $\$ 2,500.00$ \\
\hline Fencing/Panels & $\$ 150.00$ \\
\hline Miscellaneous & $\$ 50.00$ \\
\hline & \\
\hline Total & $\mathbf{\$ 2 , 7 0 0 . 0 0}$ \\
\hline
\end{tabular}

\begin{tabular}{|l|l|}
\hline \multicolumn{2}{|c|}{ Equipment } \\
\hline Item & Budgeted \\
\hline Feeding Supplies & $\$ 20.00$ \\
\hline Watering Supplies & $\$ 30.00$ \\
\hline Storage & $\$ 40.00$ \\
\hline Miscellaneous & $\$ 25.00$ \\
\hline Total & $\$ 115.00$ \\
\hline
\end{tabular}

\begin{tabular}{|l|l|}
\hline \multicolumn{2}{|c|}{ Supplies } \\
\hline Item & Budgeted \\
\hline Grooming & $\$ 20.00$ \\
\hline Showing & $\$ 30.00$ \\
\hline Miscellaneous & $\$ 50.00$ \\
\hline & \\
\hline Total & $\mathbf{\$ 1 0 0 . 0 0}$ \\
\hline
\end{tabular}

\section{Operating Costs}

\begin{tabular}{|l|l|}
\hline \multicolumn{2}{|c|}{ Maintenance } \\
\hline Item & Budgeted \\
\hline Feed & $\$ 250.00$ \\
\hline Minerals & $\$ 25.00$ \\
\hline Bedding & $\$ 100.00$ \\
\hline & \\
\hline & \\
\hline Total & $\$ \mathbf{3 7 5 . 0 0}$ \\
\hline
\end{tabular}

\begin{tabular}{|l|l|}
\hline \multicolumn{2}{|c|}{ Animal } \\
\hline Item & Budgeted \\
\hline Purchase Cost & $\$ 250.00$ \\
\hline Washing & $\$ 20.00$ \\
\hline Miscellaneous & $\$ 25.00$ \\
\hline & \\
\hline & \\
\hline Total & $\mathbf{\$ 2 9 5 . 0 0}$ \\
\hline
\end{tabular}

\begin{tabular}{|l|l|}
\hline \multicolumn{2}{|c|}{ Project } \\
\hline Item & Budgeted \\
\hline Entry Fees & $\$ 50.00$ \\
\hline Travel & $\$ 50.00$ \\
\hline Marketing & $\$ 25.00$ \\
\hline Buyer Thank-You Gift & $\$ 25.00$ \\
\hline Miscellaneous & $\$ 0.00$ \\
\hline Total & $\mathbf{\$ 1 5 0 . 0 0}$ \\
\hline
\end{tabular}

\section{Project Income}

\begin{tabular}{|l|l|}
\hline \multicolumn{2}{|c|}{ Final Sale } \\
\hline Item & Budgeted \\
\hline Sale & $\$ 840.00$ \\
\hline & \\
\hline Total & $\mathbf{\$ 8 4 0 . 0 0}$ \\
\hline
\end{tabular}

\begin{tabular}{|l|l|}
\hline \multicolumn{2}{|c|}{ Monetary Support } \\
\hline Item & Budgeted \\
\hline Sponsorships & $\$ 0.00$ \\
\hline Money Donations & $\$ 0.00$ \\
\hline Total & $\mathbf{\$ 0 . 0 0}$ \\
\hline
\end{tabular}

\begin{tabular}{|l|l|}
\hline \multicolumn{2}{|c|}{ In-Kind Support } \\
\hline Item & Budgeted \\
\hline Donated Items & $\$ 0.00$ \\
\hline & \\
\hline Total & $\mathbf{\$ 0 . 0 0}$ \\
\hline
\end{tabular}

\section{Project Outlook}

\begin{tabular}{|l|l|l|l|}
\hline \multicolumn{4}{|c|}{ Project Costs } \\
\hline Category & Category & Subtotal & Overall Total \\
\hline Housing & $\$ 2,700.00$ & $\$ 2,915.00$ & $\$ 3,735.00$ \\
\hline Equipment & $\$ 115.00$ & & \\
\hline Supply & $\$ 100.00$ & & \\
\hline Raising & $\$ 375.00$ & $\$ 820.00$ & \\
\hline Animal & $\$ 295.00$ & & \\
\hline Project & $\$ 150.00$ & & \\
\hline
\end{tabular}

\begin{tabular}{|l|l|}
\hline \multicolumn{2}{|c|}{ Project in Review } \\
\hline Project Final Weight at Sale & 280 \\
\hline Break-Even Sale Price per lb & $\$ 2.93$ \\
\hline Net Income & $\$ 20.00$ \\
\hline
\end{tabular}

